\title{
The Involvement of Mary Magdalene in the Sacrificial Death of Jesus on The Cross: Lessons for the Nigerian Christian Women
}

\author{
Jibromah, Oghenekevwe K. (Mrs.) \\ Sangotunde, Sunday $\mathrm{O}$. PhD \\ Department of Religious Studies, \\ Adeyemi Federal University of Education, Ondo, Nigeria
}

Doi: 10.19044/esj.2018.v14n2p121 URL:http://dx.doi.org/10.19044/esj.2018.v14n2p121

\begin{abstract}
One major concept that runs through all religious institutions and communities is the practice of 'sacrifice'. This idea also runs through both the Old and the New Testaments. The world in which the Bible authors inhabited was filled with physical equipments and sacred spaces of sacrifices, from massive temple to rustic country shrines, to tiny household altars. It was made up of interwoven relationships that were reinforced by sacrificial practices. Throughout the book of Leviticus, the idea of appeasement of Yahweh through series of sacrificial acts perfused the entire pages of the book. The death of Jesus Christ on the cross as the final sacrificial rite is the foundation of the Christian faith. Women are generally not considered as occupying important position in the Jewish religious culture and this idea is almost transmitted into the religious arrangement of many denominations today due to some complexities engendered by Paul's teachings in some of his epistles. Women had played major role on Christ sacrificial death on the cross, although little has been mentioned about them. Hence, the study investigates women's involvement during Christ crucifixion on the cross focusing basically on Mary Magdalene. The paper adopts textural analysis of the related verses. It also makes use of exegetical method as an approach to unveil the textual relevance of the selected texts to the subject matter. It reveals the positive role played by this woman during the sacrificial death of Christ on the cross in the interface of the expected roles of Nigerian Christian women in the ecclesiastical community. The paper concludes that women played significant role during Jesus' sacrificial death which is worthy of emulation by women participating in Christian ministries in Nigeria.
\end{abstract}

Keywords: Religion, Christianity 


\section{Introduction}

The purpose of this article is to examine the positive roles played by Mary Magdalene in the four Gospels and her involvement in Jesus' passion and sacrificial death on the cross. So much have been said on the issue of relegation of women to the background in Jewish religious culture. Jesus lived in the social cultural context of the Jews and perhaps a larger Greco-Roman society which was patriarchal. ${ }^{1}$ The patriarchal view of women was usually negative, and the place of women was understood to be limited to the domestic role of wife and mother. ${ }^{2}$ Some scholars such as Mepyer have argued that negative picture within Judaism was greatly shaped and influenced by Greek and Greco-Roman 'rocentrism and misogynism' while some others have argued that the place of women in Israel began to decline with the emergence of a bureaucratic monarchy, prior to Greek influence. ${ }^{3}$

Women were perceived by extant male writers to be responsible for most if not all sin, and especially for sexual temptation and $\sin ^{4}$. There are, on the other hand, clear indications both from literary and non-literary sources that women played positive roles in the society like their male counterparts as well. Hence this article is specifically carried out to examine the significant roles played by Mary Magdalene with the interface of the anticipated roles of Nigerian Christian women in the ecclesiastical community. This article acknowledges Mary Magdalene as a reputable feminine character among the male dominated salvific events.

It is generally acknowledged that Jesus accorded women high regard during his earthly ministry. He showed them compassion in the face of marginalization and judgementalism, no wonder these women were ready to follow him to anywhere at the risk of their lives. In the gospels women played significant role in his messianic ministry. ${ }^{5}$ Adeyanju captures the thought of Russell well as below:

"Godly women stand in Jesus' life and ministry: Elizabeth,Mother of his forerunner (Luke. 1); the Virgin Mary; Anna(2:36-38); the sinner Luke 2:36-40; Mary Magdalene;Martha and Mary of Bethany; the woman who provided for them out of their means (8:93) women remained at the cross until the burial and were first at the empty Tomb. Women joined the men in prayer between the Ascension And Pentecost" (Act 1:14.) ${ }^{6}$

The synoptic Gospels have at least no fewer than thirty-two references to women among whom most not all received better treatment in the ministry and teachings of Christ against prevailing socio-cultural norm of the time. 


\section{Attitude of Jesus to Women in the Gospels}

The success story of Jesus' sacrifice on the cross will not be complete without the role played by women. Their major contributions to Christ's sacrificial death on the cross cannot go uncommended. The story of Jesus' death cannot be told without mentioning the name of some significant women and the significant roles they played.

When referring to the earliest followers of Jesus, the Gospel writers often speak of two groups of disciples: the Twelve and the women. The Twelve refer to the twelve Jewish men chosen by Jesus to be his closest companions and the first apostles, symbolic of the twelve tribes of Israel. The Women refer to an unspecified number of female disciples who also followed Jesus, welcoming him into their homes, financing his ministry, and often teaching the twelve through their acts of faithfulness and love. Just as Jesus predicted, most of the twelve abandoned him at his death (John 16:32). But the woman remained by him through his death, burial, and resurrection.

What we must not miss in the gospels is the responses of these marginal groups to the love of God and to the concern of Jesus. The most interesting example of response to Jesus' egalitarian activity with this marginalized groups is noted by Luke where he presents the women of Jerusalem lamenting his going up to Calvary to be crucified thus: "And there followed him a great multitude of people and women who bewailed and lamented him" (23:27). This paper observed the grateful recognition of Jerusalem's women for his work for them and their predicaments of terrible days coming upon the city after murdering such prophets as Jesus. ${ }^{7}$ "The only record of financial support given to Jesus is in Luke. "And certain women ...ministered unto him of their substance" (Luke 8: 2, 3).

The synoptic lists are arranged perhaps in order of importance or familiarity both in relationship to the Gospels were women followers of Jesus are mentioned Mary, Magdalene's name is placed first (except in John 19:25 where there's special interest in the mother of Jesus). Mary Magdalene's first place was only because of her loyalty to Jesus or notable service but also (and perhaps primarily) because of her witness about the risen Lord. These particular lists of those at the crucifixion may be the lists of those who saw and witnessed about the risen Lord. The first Evangelist and Mark refer to these women's service to Jesus (Mark 15:41, Matthew 27:55) a fact noted in Luke 8:3 (though there the twelve are among those served), and thus not repeated by Luke here. All the three accounts speak of these women as followers of Jesus. In Mark we were told they served ( $\dot{\eta} \kappa o \lambda o v \theta \theta v v$ ) him when he was in Galilee. The first evangelist says they served ( $\dot{\kappa} \kappa \lambda \circ v \theta \eta \sigma \alpha v$ ) Jesus from Galilee, while Luke says they ( $\sigma v v \alpha \kappa o \lambda o v \theta o v \sigma \alpha)$ him from Galilee. ${ }^{8}$ 


\section{Mary Magdalene}

Mary Magdalene or Mary of Magdala (original Greek Mapía ウ́ M $\alpha \gamma \delta \alpha \lambda \eta v \eta$ ) is described, in the New Testament, as one of the most important women in the movement of Jesus throughout his ministry. Consistently in the four Gospels, Mary Magdalene seems to be distinguished from other women named Mary by adding "Magdalene" ( $\eta$ M $\alpha \gamma \delta \alpha \lambda \eta v \eta$ ) to her name. Traditionally, this has been interpreted to mean that she was from Magdala, a town known to be on the western shore of the Sea of Galilee. Luke 8:2 says that she was actually called "Magdalene".In Hebrew Migdal means "Tower", "Fortress", in Aramaic, "Magdala" means "Tower" or "Elevated, Great, Magnificent". Not to confused Mary bearing a title of Greatness. ${ }^{9}$

In the Gospel of John, Mary Magdalene is also referred to simply as "Mary" at least twice, Gnostic writings use either Mary or Mary Magdalene, or even just Magdalene. Mary Magdalene given name Mapía (Maria) is usually regarded as a Latin form of Mapía (Mariam), which is the Greek variant used in Septuagint for Miriam, the Hebrew name for Moses' sister. The name had become very popular during Jesus' time due to its connections to the ruling Hasmonean and Herodian dynasties. ${ }^{10}$

The late $20^{\text {th }}$ and early $21^{\text {st }}$ century has seen a restoration of the New Testament figure of Mary Magdalene as a patron of women's preaching and ministry. Her new popularity defamation stemmed in part from the recognition that Mary Magdalene has suffered from what some believe to have been a historical defamation of character. She has been thought to be misidentified as a repentant prostitute in historical tradition and depicted in Art as a weeping sinner wiping Jesus feet with her hair. Some New Testament scholarship has shown that this picture of Mary Magdalene is not true. ${ }^{11}$

According to Luke 8:2 and Mark 16:9, Jesus cleansed her of "seven demons", a concept usually associated in the new testament with healing from illness, and forgiveness of sin, Mary Magdalene is the leader of a group of women disciples who are present at the cross, when the male disciples (except John the Beloved) has fled, and went into hiding and at his burial. Mary was a devoted follower of Jesus, entering into the close circle of those taught by Jesus during his Galilean ministry. She became prominent during the last days, accompanying Jesus during his travels and following him to the end. She witnessed his crucifixion and burial. According to all the four Gospels of the Christians New testament, she was the first person to see the resurrected Christ. $^{12}$

\section{Gospel Records of Mary Magdalene: A Lesson for African Christian Women}

The four Gospels have some clear and profound twelve references to Mary Magdalene linking her with events and activities woven around Jesus at 
different notable points of His ministry especially that are intimately connected with the passion and the crucifixion of Jesus. The description of her as Mary Magdalene is the feminine noun of a derivative of Magdala which connotes that this Mary is an inhabitant of a community called Magdala; a small community of the coast of the sea of Galilee near Tiberias. ${ }^{13}$ Today Magdala is a place of encounter and dialogue between Jews and Christians, it is a place where archaeology meets faith and where stones come alive during digging of monuments to further enrich researches on Christianity. ${ }^{14}$ Whatever the origin, this "nickname" helps us distinguish her from the half-dozen Marys mentioned in the Bible. Of course, the most distinguishing characteristic about Mary is that Jesus cast seven demons out of her (Luke 8:2-3). African Christian women should familiarize themselves with humble beginning and need to know that God appreciates small beginning like that of Mary Magdalene.

With a single exception in the Gospel of Luke, there is no mention of her in the Gospels before the crucifixion, Luke 8:1-3:

"After this, Jesus traveled about from one town and village.

To another-the twelve were with him, and also some women

Who had been cured of evil spirits and diseases, Mary

(Called Magdalene) from whom seven demons had come

Out-and many others. These women were helping to support

them out of their own means."

That Mary Magdalene was a prostitute is just one of the many depictions of her put forward over the centuries. ${ }^{15}$ She has also been misrepresented to be the seductress of Jesus (for instance the film "The Last Temptation of Christ"), Jesus's wife (a myth debunked by Duke scholar Mark Goodacre - see note below), or a promiscuous woman. However, it is observed that none of these claims are supported by the biblical texts. The same reference to "seven demons" is made in Mark 16:9. his part of the Gospel of Mark is generally regarded as a late addition, and the reference is possibly based on the Gospel of Luke. The characterization of Mary Magdalene as an adulteress or prostitute shows up several hundred years after the time of Christ when her identity was merged with that of the sinful woman who anoints Jesus' feet (Luke 7:36-50).

Wallage Gail observed that this "composite Magdalene" was popularized in a sermon given by Pope Gregory I around 591 AD. Here is an excerpt:

"She whom Luke calls the sinful woman, whom John calls Mary, we believe to be the Mary from whom seven devils were ejected according to Mark. And what did these seven devils signify, if not all the vices? It is clear, brothers, that the woman previously used the unguent to perfume her flesh in forbidden acts... What she therefore displayed more scandalously, she was 
now offering to God in a more praiseworthy manner." - Pope Gregory the Great (Homily XXXIII). ${ }^{16}$

One the most important lessons for African women to learn from Mary is the depth of her devotion to Jesus. The gospel writers are specific in noting that Mary and a number of other women had followed Jesus from Galilee (Matthew 27:55). The first mention of her is in Luke 8:2-3, so we know that she was with Jesus from the beginning of his ministry. The last mention is in John 20, where we find Jesus appearing to her at the empty tomb. She was very prompt and accurate and would never miss any major happening surrounding Jesus. She was not agitating to out live the apostles but she followed with the mind of attending to the special needs of Jesus. Thereby Mary established a new and an enduring ministry aside of the ministry of preaching the gospel for which the male disciples were called into. There are clear indications that Mary left home and all that she had to follow Jesus for most of his three years public ministry.

After giving her report that Jesus had risen, Mary Magdalene disappears from the New Testament. But we find some clues about her later life in extra-biblical texts. The apocryphal gospels depict Mary as a disciple who has a deep understanding of Christ's teachings.

Several early church writers portray her as a leader in the early church movement. At some point she was given the title "Apostle to the Apostles", because she was the first person to see the risen Christ and the first to share the news of the resurrection with the disciples. ${ }^{21}$ Mary was an epitome of a female Evangelist, a title earned by her zeal in spreading the goodnews of Jesus' resurrection without the fear of the Jews.

In the light of the on-going conversations about the role of women in the Catholic Church it is interesting that Pope Benedict XVI had this to say in a 2007 address:

"St. Thomas Aquinas reserved the special title, "Apostle of the Apostles" (apostolorum apostola), dedicating to [Mary Magdalene] this beautiful comment: 'Just as a woman had announced the words of death to the first man, so also a woman was the first to announce to the Apostles the words of life" (Super Ioannem, ed. Cai, § 2519). ${ }^{17}$

To analyze Mary Magdalene's role as major witness to the resurrection, Gerald O'Collins and Daniel K. quoting Joseph Fitzmyer, in the second volume of his commentary on Luke's Gospel, lists and describes the six Resurrection narratives which are found in the Gospel tradition. ${ }^{18}$

(a) Mark 16:1-8. The discovery of the empty tomb by the women (Mary Magdalene, Mary the mother of James and Salome). A "young man" changes them to go and tell the disciples and Peter that Jesus goes before them to Galilee, where they will see him. The women flee and say nothing to anyone, "For they were afraid". There are no appearances of the risen Christ. 
(b) Matthew 28:1-20. The discovery of the tomb by the women (Mary Magdalene and another Mary). An Angel and then Jesus appear to them and tell them to break the news to the others. Later on, the risen Christ appears to the eleven in Galilee and commissions them to make disciples, to teach, and to baptize.

(c) Luke 23:56b; 24:53. This narrative consist of five episodes: (a) the finding of the empty tomb by the women (Mary Magdalene, Mary and the mother of James, Joanna, and others); they are told by the two men I gleaming robes to recall the words that Jesus had addressed to them while he was still in Galilee; the women leave and report it all to the eleven, who regarded their stories as so mush nonsense; Peter alone goes off to see for himself (and then the risen Christ appears to him). (b) the risen Christ appears to the disciples on the road to Emmaus; (c) Christ appears to the Eleven and their companions in Jerusalem; $(d)$ he commissions them to be "witness of this" and to preach in his name; and $(e)$ he leads them out of Bethany, where he parts from them and is carried off to heaven on Easter Sunday night.

(d) John 20:1-29. The discovery of the empty tomb by Mary Magdalene, who tells Simon Peter and the beloved disciple. This is followed by the appearance of the risen Christ to Mary, his appearance to his disciples in Jerusalem on Easter Sunday evening, with Thomas absent, and his appearance a week later, with Thomas present.

(e) John 21:1-23). The risen Christ appears to seven the second is two disciples who have been fishing on the sea of Tiberius, after which Simon Peter is commissioned to feed Christ's sheep. This section presents the contracting roles of Peter and the beloved disciple.

(f) Mark 16:9-20. Three appearances in the Jerusalem area on the first day of the week. The first of these is to Mary Magdalene; the second is to two disciples waking into the country, who go back and report it to disbelieving disciples; the third is to the eleven, who Christ upbraids for disbelieve and finally commission to preach the Gospel to all creation. Christ is then taken up into Heaven, seated at the right hand of God, and the disciples go forth to preach. Out of the six gospel narrative Mary Magdalene is mentioned five times while Peter was mentioned only four times and together with Mary Magdalene. ${ }^{19}$

\section{The sacrificial Roles played by Mary Magdalene}

Mary Magdalene was one of the women standing at a distance, they were bewildered, heartbroken, drenched, in sorrow but they were there. They loved Jesus so much that they could not leave him but chose to serve him till death even when all the female disciples could not stand around because of the fear of attack by the Jewish authority. Love clings to Christ even when the 
intellect cannot understand; it is only love which can give us a hold on Christ that even the most following experience cannot break. ${ }^{20}$

In Mark, we have the following women listed: Mary Magdalene, Mary the mother of James the younger and Joseph, and Salome while in Matthew's account, Mary Magdalene, Mary the mother of James and Joseph and the mother of the sons of Zebedee were mentioned. In Luke, we have no specific list, but Luke says these women at the cross are those who had followed Jesus from Galilee among who were Mary Magdalene; Joanna and Susanna wife of Chuza Herod's steward. In John, we have four women listed: the mother, of Jesus, the sister of Jesus mother, Mary of Cleopas and Mary of Magdalene. Even though the first Evangelist is almost certainly following Marks it is not certain whether he has omitted Salome's and the mother of Zebedee. While Mary of Cleopas may be the mother of James and Joseph, it may also be that these are two different people. All the four accounts speak of these women as followers of Jesus. $^{21}$

It is striking that all the four Gospels agree in listing Mary Magdalene as a formidable character around the cross and it appears that Mk. 15:40, Mt. 15:56, Lk. 24:10 share at least two names in common. The fourth evangelist has special reason to list Jesus' mother and it is strange that she was omitted in the synoptic if she is actually present. "Now there stood by the cross of Jesus his mother, and his mother's sister. Mary the wife of Cleopas and Mary Magdalene"(John 19:25). The last person at the cross was a woman and this was Mary Magdalene (Mark 15:47).

In serving him, the women such as Mary Magdalene served as Jesus served (Mark 10:45; 1:31; 15:41). Nigerian Christian women should serve faithfully and sincerely like these women. Not once was the reader told that the twelve disciples served. But a specific connection is made between Christ's sacrificial death on the cross, the Eucharist, and the table service rendered by the women. The submitting to the death of the by Jesus was a service offered for the redemption of humanity and is reflected in the table service rendered by the women, where bread was offered, and the table service of the Eucharist, where the bread of life is offered. It is no accident that the women alone were described as serving in many places in the gospel. Mark depicted them as true servants of Christ and Pual described them as stewards of God's mysteries' (1 Cor 4:1). They alone are shown doing what disciples are called by Christ to do (Mark 15:41). This is an important lesson for Nigerian Christian women today.

The final dimension of discipleship according to Mark is proclamation of the good news of Jesus to all the nations (13:14). Proclamation consist of clear and living evidences that Jesus' followers are willing to give themselves in total self-sacrifices. This lived proclamation results in the acclamation of Jesus speaks in rapid succession of proclaiming the Gospel to all the nations 
(13:10) and enduring to the end (13:13). Before and after the discourse the reader is shown two women; Mary Magdalene was one of the two who were willing to give their all, to spend their life and to endure to the end. ${ }^{22}$

With the exception of the beloved disciples (John 19:26), Mary Magdalene and the other Mary were the only followers of Jesus who accompanied him through the agony of the crucifixion (John 27:25; Matt27:55; Mark 15:40), and then lovingly attended his burial (Matt 27:61; Mark 15:47). The risen Jesus appeared first to Mary of Magdalene, and then commissioned her to bring the news to the disciples (John 20:11-18; see also Matt 28:7; Luke 24:10). She is usually the first one named in list of Jesus' female followers (e.g. Mark 15:40; 16:1); she is the first lamb named by the risen Lord Jesus and counted as a member of doing flock (John 20:16). No elaboration required of the numerous gospel stories where women were held up as examples of faith and fervent prayer, hope and sacrificial love. ${ }^{23}$

Mark distinguishes between those women who followed Jesus when he was in Galilee and many other women who came up with Jesus into Jerusalem. The discipleship status of the named women is indicated by Mark in three ways: they are said (1) to be witness of the most crucial events in

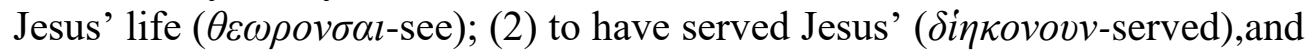

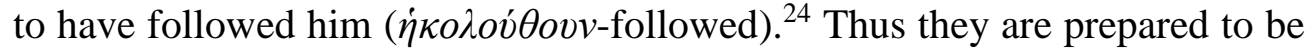
reliable witness to the events beginning with the crucifixion.

In Mark, It is made up of the women who have had insight to recognize Jesus as God's word, willing to respond and self-commitment to his service. These women have played significant role in the redeeming work of Christ in the world, which can never be reckoned. So much that is great and noble in the Christian story has come through them, wives, mother, friends, teachers, helpers and fighters in Christ cause. So much of the work of the kingdom of God is done by them. So much of the hope of the future victory of Christianity depends on them. ${ }^{25}$

All the four Gospel report the female disciples of Jesus were the first ones to receive the angelic account of Jesus' resurrection and commission to go and tell the male disciples of this event (Mt 28:1-8; Mk 16:1-8; Luke 24:112; see John 20:1-13). According to Luke (Luke 24:10-11, 22-24) the men did not believe the report of the women (see Mk 16:11 in the long addition to Mark). Further, the Gospels of Matthew and John and the long ending of Mark report that Jesus appeared first to Mary Magdalene (John 20:14-18; Mk 16:911; in Mt 28:9-10 the other Mary \{ see Mt 27:61; 28:1\} is with Mary Magdalene; this other Mary is presumably Mary the Mother of James the younger and Joseph, mentioned in (Mt 27:56).

The Gospel of Matthew and John and the long ending of Mark report that Jesus appeared first to Mary Magdalene and commissioned her to tell the male disciples what she has seen and heard. (John20:14-18; Mark 16:9-11; 
Matthew 28:9-10) the role of women as the first witness of Jesus resurrection was very significant in the Gospel tradition and is important to the discussion of the significance of Jesus' relationship to women for the church today. ${ }^{26}$ This also will validate the submission of Okunlola, that "among all the creature in the earth, the woman is not a mean value...... she has such value upon which the value of many other creatures depends." 27 In Mark, It is made up of the women who have had insight to recognize Jesus as God's word, willing to respond and self-commitment to his service. So much of the work of the kingdom of God is done by them. So much of the hope of the future victory of Christianity depends on them. ${ }^{28}$

More than any other Gospel, John revises this tradition about Peter. Matthew 28:9-10 recalls that the women who were leaving the empty tomb were the first to encounter the risen Jesus, but in Matthew they were also contrasted with Peter. In John 20:2-10 Simon Peter and the beloved Disciple go to the empty tomb and do not see Jesus (also Luke 24:12-24). In fact, only the beloved disciple perceived the significance of the grave cloths and goes on to tells his brothers; (the disciples; 20:17 and 18) of his ascension to the father. ${ }^{29}$ In the stories of the Angels at the empty tomb, the women were given a message for the disciples: but in John (and in Matthew) Mary Magdalene is sent by the risen Lord himself, and what she proclaim is the standard apostolic announcement of the resurrection; 'I have seen the Lord'. True, this is not a mission to the whole world; but Mary Magdalene comes close to meeting the basic Pauline requirement of an apostle; and it, was she, not Peter, who was the first to see Jesus. It is there not surprising that in some Gnostic quarter Mary Magdalene rather than Peter became the most prominent witness to the teaching of the risen Lord. ${ }^{30}$

\section{Conclusion}

Considering the historical background of the event of Jesus' passion, crucifixion and resurrection, this article presumes the risk the women took to be associated with Jesus. The women's role in the ministry of Jesus in no small measure made it possible for him and the disciples to give their time to the proclamation of the Kingdom without having to spend time and energy to organized food and accommodation. They played a major role in the ministry of Jesus both in the good times and in the darkest hours of his passion, death and burial. The single act of Mary Magdalene and the other women in the ministry of Jesus has spore generation of women to rise up to the task of promoting the Jesus' movement.

Mary Magdalene remains the only link to our Christian foundation. The role played by Mary (Magdalene) in announcing the resurrection of Jesus cannot but be commended.

Thus, it could reasonably be concluded that in talking about sacrifice 
in religious tradition, Mary Magdalene stood out as tower of strength to generations of women in breaking the barrier and the relegation of women to the background in most religious traditions, and patriarchal communities all over the world. This fact enables the scholars to conclude that there are still inspiring women both in academics, ministries, NGOS, secular world and contemporary societies and so on in Africa and particularly in Nigeria who are endowed greatly to promote the cause of humanity all over the world and fight against marginalization of women in politics and religious spheres.

\section{References:}

1. Daniel ,C, Ullucci, The Christian Rejection of Animal Sacrifice: Sacrifice in the New Testament, (New York: Oxford University Press, 2012). Retrieved: www.oxfordbiblical studies.com/resou....

2. Mepyer, C. Discovering Eve: Ancient Israelites Women in Context. (New York: Oxford University, 1938: 12.

3. Mepyer, C. Discovering Eve, 1938:12.

4. Olubayo O. O, "Women's Role in Jesus Ministry in the African (Yoruba) context". A Paper Presented for NABIS Western Conference, March 5-9, 2012 in Honor of Dr. O. Akintude; University of Ibadan, Ibadan.

5. Luke 8:1-3

6. Adeyanju, J. O “Jesus' Attitude to Women in the Gospels: A Recipe for Women's Involvement in the Socio-Religious Transformation of Nigeria' (in Biblical studies and Feminism in the African Context. Olabiyi A. Adewale et al (Editors). A Publication of the Nigeria Association for Biblical studies 3 (NABIS Western Zone, 2012.P.179.

7. Savvas Agouridis. "Women in the Work of the Church: An exegetical Contribution to the New Testament": Anglican Theological Review ATR/LXXXIV.3 Theological Faculty, University of Athens. (n. d.) p. 501, 511.10. @www.atr/lxxxivtheological.athens.edu.com. Accessed on 14th March,2017.

8. Witherington, Ben 111. Women in Jesus Ministry. New York: Cambridge University Press, 1984:121.

9. Witherington, Ben 111. Women in Jesus Ministry, 1984:121.

10. Wikipedia: Various information on Mary and Martha: were Mary Magdalene and Martha and Lazaraus Siblings? @ www.hildersham.org.uk. Accessed on $7^{\text {th }}$ March, 2017.

11. Wikipedia: Various information on Mary and Martha, Accessed on $7^{\text {th }}$ March, 2017

12. Wikipedia: Various information on Mary and Martha, Accessed on $7^{\text {th }}$ March, 2017 
13. Wallage, Gail. Mary Magdalene: Five Things You should Know. @www.http://marymagdalene.thejuniaproject.htm.2014.

14. Wallage, Gail. Mary Magdalene, 2014.

15. Burnet, $M$ and Downey, R. The Bible. In Mark Goodacre The Post and The Passion: Magdalene: Released from Shame. History Channels Series, 2013. These scholars observed that Mary Magdalene is not to be depicted as a repentant prostitute but as one who followed Jesus and ministered to him from Galilee (Mark 15: 40-41, Luke 8:1-3) to Jerusalem, to the cross( Mark 15: 40-41, John 19:25), his burial ( Mark 15:47) and his resurrection (Mark 16:1-8; John 20:1-28).

16. Wallage, Gail. Mary Magdalene: Five Things You should Know.,2014.

17. Rachel Held Evans "Women of the Passion, Part 4: Mary Magdalene, Apostle to the Apostles. April 08, 2012. Retrieved http://rachelheldevans.com/blog/women-of-thepassion-marymagdalene.

18. Rachel Held Evans "Women of the Passion, Part 4: Mary Magdalene, Apostle to Apostle.

19. Wallage, Gail. Mary Magdalene: Five Things You should Know.,2014.

20. Gerald O’Collins, S.J and Daniel Kendall, S.J "Mary Magdalene as Major Witness to Jesus' Resurrection" Theology Studies, 48; 1987:.633. Retrieved: @ cdn.theologicalstudies.net|48|.... on 21th June, 2017.

21. Gerald O’Collins, S.J and Daniel Kendall, S.J "Mary Magdalene as Major Witness, 1987.

22. Elizabeth. Platt,"The Ministry of Bethany". Theology Today, Vol. 34, No. 1 April 1977: 30.

23. Peter Lockwood, Disciples, Companion, Witness: Women in the Gospels. 15th February, 2002.(Posted in Discussion starters) Admin. Retrieved:wp.wnn.org.au/.../resoureces/united-in-christ/disciplescompanion.

24. Kopas J. "Jesus and Women: Luke Gospel, Theology Today, and vol.43/1986:192-202.

25. William Barclay, The Gospel of Mark "Revised Edition" (Philadephia: The Westminster Press, 1975:365.

26. Oderinde, O.A, “Gender Relations Lessons from Jesus' Relationship with women in Mark" (Ibadan: Korem Printer (JITW),2012:88

27. Okunlola, A. O. "The Value of a Woman: A critical and theological Interpretation of Leviticus 27: 1-8, "Biblical Studies and Women Issues in Africa. Biblical Studies Series Number 1, A Publication of 
Nigerian Association of Biblical Studies.(Ibadan: Philarem Corporate Printers, 2003:49.

28. William Barclay, "The Gospel of Mark "Revised Edition, 1975

29. Wilbur Donovan, Women in Modern African and in the Church in Biblical Christian in Modern Africa, Tottenham: Peter Moster Press: 2000.

30. Danfulani, Kore. Culture and Christian Homo. Jos Nigeria: Africa Christian textbooks, 1989:43. 